\title{
Production of type 5 capsular polysaccharide by Staphylococcus aureus grown in a semi-synthetic medium
}

\author{
B. Dassy, ${ }^{1,2}$ W. T. Stringfellow ${ }^{2} \dagger$ M. $\operatorname{Lieb}^{2}$ and J. M. Fournier ${ }^{2 *}$ \\ ${ }^{1}$ Division de Biochimie, Université Pierre et Marie Curie, Paris, France \\ ${ }^{2}$ Département d'Ecologie, Institut Pasteur, F-75724 Paris Cedex 15, France
}

(Received 22 October 1990; accepted 18 December 1990)

\begin{abstract}
The concentration of the type 5 capsular polysaccharide (CP) antigen of Staphylococcus aureus can be measured directly in cultures or cell suspensions by a two-step inhibition enzyme-linked immunosorbent assay (ELISA), using monoclonal antibodies. CP was synthesized during growth on a variety of carbon substrates and its production was not affected by the nature of the carbon source. High levels of yeast extract inhibited CP formation. CP was synthesized in batch culture at the same rate during exponential growth as in the postexponential phase. Post-exponential CP production contributed at least half the final amount of CP measured. This phenomenon was observed in different culture media, although the specific yield of polysaccharide varied from one medium to another. Post-exponential CP production was observed in the pH range 6-7, but not at pH 8. Postexponential production was strictly dependent on oxygen availability and did not occur under anaerobic conditions.
\end{abstract}

\section{Introduction}

Exopolysaccharides produced by a wide range of microorganisms are receiving increasing attention due to their participation in pathogenic and symbiotic processes in plants and animals and their involvement in general interactions between micro-organisms and their environment (Sutherland, 1988; Whitfield, 1988; Wilkinson, 1958). Moreover, some microbial polysaccharides have an industrial value due to their gel-forming or emulsifying properties, their use in the preparation of rare sugars (Luong et al., 1988; Paul et al., 1986) and their potential use as bacterial vaccines (Jennings, 1990; Robbins \& Schneerson, 1990).

The involvement of capsular polysaccharides $(\mathrm{CP})$ in the invasiveness of many bacteria is well established. The enhanced virulence of encapsulated bacteria is generally attributed to their resistance to phagocytosis (Roberts et al., 1989; Whitfield, 1988; Wilkinson, 1958).

$\dagger$ Present address: Department of Environmental Sciences and Engineering, School of Public Health, The University of North Carolina, Chapel Hill, NC 27599-7400, USA.

Abbreviations: $\mathrm{CP}$, capsular polysaccharide; $\mathrm{mAb}$, monoclonal antibody; MFM-YE, modified Frantz medium plus yeast extract diffusate; MFM-CA, modified Frantz medium plus Casamino acids diffusate.
CP may also be involved in the adhesive capacity of some bacteria (Sutherland, 1988; Whitfield, 1988).

Only a few well-encapsulated mucoid isolates of Staphylococcus aureus were identified before the 1980s. Although $S$. aureus causes bacteremia (Sheagren, 1984), it was not conclusively proved until recently that $\mathrm{CP}$ formation was common in clinical isolates of this organism (Karakawa \& Vann, 1982; Robbins \& Schneerson, 1990). The existence of CP has been demonstrated by morphological, immunological, biochemical and epidemiological studies. Transmission electron microscopy, using antibodies reacting with $\mathrm{CP}$, showed that these antigens are exposed on the surface of $S$. aureus (Chomarat et al., 1989; Hochkeppel et al., 1987; Lee et al., 1987). A classification scheme, based on direct bacterial agglutination and immunoprecipitation of cell extracts with polyclonal antisera identified eight capsular types (Karakawa et al., 1985). Several epidemiological studies of encapsulated $S$. aureus from human clinical isolates have shown that two capsular serotypes, 5 and 8 , account for about 70 to $80 \%$ of all isolates, with no strain possessing more than one serotype (Arbeit et al., 1984; Boutonnier et al., 1989; Hochkeppel et al., 1987; Sompolinsky et al., 1985).

In contrast to these areas of investigation, little is presently understood concerning the physiology and biochemistry of CP biosynthesis by $S$. aureus. Capsule 
formation is usually demonstrated with fresh isolates of human or animal origin, and repeated subcultivation on an artificial medium results in decreased capsule synthesis (Johne et al., 1989; Opdebeeck et al., 1985, 1988; Rather et al., 1986; Witte, 1975). Expression is also influenced by the medium in which capsule production is tested. Growth in Staphylococcus Medium 110, which contains high concentrations of carbohydrate and $\mathrm{NaCl}$, encourages the production of mucoid or capsular material (Caputy \& Costerton, 1984; Johne et al., 1989; Opdebeeck et al., 1988; Rather et al., 1986; Yoshida \& Ekstedt, 1968). CP production occurs in both liquid (Lee et al., 1987) and solid media (Chomarat et al., 1989; Hochkeppel et al., 1987; Johne et al., 1989). The production of CP may also be affected by the incubation period, but the few results concerning this point are incomplete and contradictory (Falcieri et al., 1987; Kitzrow et al., 1975; Wiley, 1968).

Apart from these partial findings, there is no other information available on the formation of CP by $S$. aureus grown under a range of controlled environmental conditions. An impediment to such a study has been the lack of a quantitative and specific assay for $\mathrm{CP}$ that can be applied to unpurified extracts. Recently, a staining method for the measurement of $S$. aureus $C P$ was described (Mattila, 1989). However, the use of a staining technique is not highly specific. Monoclonal antibodies (mAbs) reactive with type 5 and type $8 \mathrm{CP}$ of $S$. aureus have now been developed and allow the measurement of $\mathrm{CP}$ concentration directly in cultures and cell suspensions by a two-step inhibition, enzyme-linked immunosorbent assay (ELISA) (Albus et al., 1988; Boutonnier $e t$ al., 1989; Poutrel et al., 1988).

The work reported here is part of an investigation undertaken to assess the effects of medium composition and environmental factors on the production of type 5 $\mathrm{CP}$ by $S$. aureus when grown in batch culture. For the present study, we compared several classic media for type $5 \mathrm{CP}$ production and selected the most efficient, which was a semi-synthetic medium. The time course of growth and CP production was followed in this medium, and the influence of medium composition, $\mathrm{pH}$ and dissolved oxygen was examined.

\section{Methods}

Bacterium. S. aureus strain Reynolds is the prototype strain for type 5 CP (Fournier et al., 1987; Karakawa et al., 1985). It was stored lyophilized or in deep agar slants.

Culture media. The following classic media were used: Brain Heart Infusion (Difco), Nutrient Broth (Diagnostics Pasteur, France), Mueller-Hinton, Columbia and Staphylococcus Medium 110 (all Difco).

Frantz medium, a semi-synthetic medium for the production of capsular polysaccharide by Neisseria meningitidis (Gottschlich et al., 1969), was modified for the cultivation of $S$. aureus. The basal medium contained (1-1) $1.3 \mathrm{~g}$ glutamic acid, $12 \mathrm{mg}$ cystine, $0.4 \mathrm{~g} \mathrm{MgCl}_{2} .6 \mathrm{H}_{2} \mathrm{O}$, $5.7 \mathrm{~g} \mathrm{Na}_{2} \mathrm{HPO}_{4} .12 \mathrm{H}_{2} \mathrm{O}, 6 \mathrm{~g} \mathrm{NH}_{4} \mathrm{Cl}, 90 \mathrm{mg} \mathrm{KCl}, 6 \mathrm{~g} \mathrm{NaCl}$ and $2 \mathrm{~g}$ lactose. The basal medium was adjusted to $\mathrm{pH} 6.5$ with $\mathrm{NaOH}$ and supplemented with $2 \%(\mathrm{v} / \mathrm{v})$ yeast extract diffusate (MFM-YE) or with $2 \%$ (v/v) Casamino acids diffusate, $1 \mathrm{mg}$ thiamin and $1 \mathrm{mg}$ nicotinamide (MFM-CA). The diffusates were obtained as follows: $100 \mathrm{~g}$ yeast extract (Difco) or Casamino acids (Difco) were placed in a dialysis bag and submerged in $500 \mathrm{ml} 9 \mathrm{~g} \mathrm{NaCl}^{-1}$ for $2 \mathrm{~d}$ at $4{ }^{\circ} \mathrm{C}$ with a magnetic stirrer. About $250 \mathrm{ml}$ of diffusing material was obtained, and sterilized by filtration.

Nine $\mathrm{ml}$ of the above media, supplemented with $1.5 \%(\mathrm{w} / \mathrm{v})$ agar (Difco), was placed in $17 \mathrm{~mm}$ screw cap tubes, to make agar slants.

Growth conditions. Bacteria were grown either on agar slants, in flasks, or in a 61 fermenter, at $37^{\circ} \mathrm{C}$.

Unless otherwise specified, agar slants were incubated with loose caps permitting good air exchange. After growth, bacterial cells were washed from the agar slant and suspended in $10 \mathrm{ml}$ phosphate-buffered saline, $\mathrm{pH} \mathrm{7,} \mathrm{for} \mathrm{analysis} \mathrm{and} \mathrm{flask} \mathrm{inoculation.}$

Flasks were inoculated with an overnight culture from the same medium, and placed in a rotary water-bath shaker (200 r.p.m.).

The fermenter had a working volume of 4.51 and was equipped with a draft-tube agitation system (Biolaffite, France). An autoclavable, galvanic-type electrode was used to measure dissolved oxygen tension, expressed as percentage saturation. The $\mathrm{pH}$ was automatically controlled by the addition of $1 \mathrm{M}-\mathrm{NaOH}$ or $1 \mathrm{M}$-acetic acid. The culture was agitated at a constant speed of 500 r.p.m. and aerated at a rate of 31 of air $\min ^{-1}$. For anaerobic culture, nitrogen gas was used instead of air at a rate of $11 \mathrm{~min}^{-1}$. The fermenter was inoculated with $100 \mathrm{ml}$ of an overnight culture from the same medium in a shake flask, and samples containing cells suspended in the growth medium were taken for analysis.

Bacterial growth was followed by measuring the optical density of an appropriate dilution of the cell suspension at $620 \mathrm{~nm}\left(\mathrm{OD}_{620}\right)$. For 1 $\mathrm{OD}_{620}$ unit, plate counts of viable organisms gave a mean value of $5 \times 10^{9}$ bacteria $\mathrm{ml}^{-1}$ and dry weight determinations a mean value of $0.4 \mathrm{mg} \mathrm{ml}^{-1}$. This relationship was observed with all the media used.

Type 5 CP assay. Bacterial cell suspensions were autoclaved at $121^{\circ} \mathrm{C}$ for $30 \mathrm{~min}$, to release type $5 \mathrm{CP}$ from the cell (Fournier et al., 1987). After centrifugation, the supernatant was retained and stored at $-20^{\circ} \mathrm{C}$ prior to type $5 \mathrm{CP}$ assay. For samples taken from broth cultures, this supernatant contained total $\mathrm{CP}$ (cell-bound $\mathrm{CP}$ plus culture fluid $\mathrm{CP}$ ).

For comparison, type $5 \mathrm{CP}$ was also extracted by addition of lysostaphin (Sigma) at $0.1 \mathrm{mg} \mathrm{ml}^{-1}$ to cell suspensions, incubation at $37^{\circ} \mathrm{C}$ overnight, and centrifugation. These conditions have been shown to give optimal lysis (Huber \& Huber, 1989). The CP contents determined in the supernatants were not significantly different for autoclaving and lysostaphin lysis.

Type 5 CP content was determined by a two-step inhibition ELISA using mAbs as previously described (Boutonnier et al., 1989). In step one, mAbs were bound to $\mathrm{CP}$ present in the samples. A plate was blocked with $0.5 \%(\mathrm{w} / \mathrm{v})$ gelatin in PBS at $37^{\circ} \mathrm{C}$ for $1 \mathrm{~h}$. After washing with PBS/Tween, the wells received $100 \mu \mathrm{l}$ volumes of test samples and $100 \mu \mathrm{l}$ of mAbs diluted in PBS/Tween, supplemented with $0.5 \%$ gelatin, to a concentration giving a final $A_{492}$ of $0 \cdot 2-0.5$ as determined by preliminary titration. In step two, $C P$ was quantified by measurement of non-bound antibodies remaining after step one using $\mathrm{CP}$-coated microtitre plates. After incubation at $37^{\circ} \mathrm{C}$ for $1 \mathrm{~h}$ and then overnight at $4{ }^{\circ} \mathrm{C}, 100 \mu \mathrm{l}$ samples from each well of the original plate one were transferred to a second plate which had been previously coated with purified $\mathrm{CP}$ and blocked with gelatin. This plate was incubated at $37^{\circ} \mathrm{C}$ for $1 \mathrm{~h}$ and, after washing with PBS/Tween, 
Table 1. Type 5 CP production by $S$. aureus strain Reynolds grown for $24 \mathrm{~h}$ on agar slants

Data shown are one representative set of data from four separate experiments.

\begin{tabular}{|c|c|c|c|c|c|c|}
\hline \multirow[b]{2}{*}{$\begin{array}{l}\text { Agar } \\
\text { slant }\end{array}$} & \multicolumn{3}{|c|}{ Loose cap } & \multicolumn{3}{|c|}{ Airtight cap } \\
\hline & $\mathrm{OD}_{620}$ & $\begin{array}{c}\text { Type } 5 \text { CP } \\
\left(\mu \mathrm{g} \mathrm{ml}^{-1}\right)\end{array}$ & $\begin{array}{l}\text { Final } \\
Y_{\mathrm{CPS}}{ }^{*}\end{array}$ & $\mathrm{OD}_{620}$ & $\begin{array}{c}\text { Type } 5 \text { CP } \\
\left(\mu \mathrm{g} \mathrm{ml}^{-1}\right)\end{array}$ & $\begin{array}{l}\text { Final } \\
Y_{\mathrm{CP} 5}{ }^{*}\end{array}$ \\
\hline Brain Heart Infusion & $5 \cdot 43$ & $2 \cdot 840$ & 0.523 & $1 \cdot 70$ & 0.014 & 0.008 \\
\hline Nutrient Broth & $1 \cdot 59$ & 0.910 & 0.572 & $1 \cdot 02$ & $0 \cdot 195$ & $0 \cdot 191$ \\
\hline Mueller-Hinton & $1 \cdot 06$ & 0.638 & 0.602 & 0.79 & 0.095 & $0 \cdot 120$ \\
\hline Columbia & $2 \cdot 38$ & 0.939 & 0.395 & $1 \cdot 50$ & 0.057 & 0.038 \\
\hline Medium 110 & 1.89 & $4 \cdot 773$ & $2 \cdot 525$ & $1 \cdot 02$ & $0 \cdot 167$ & $0 \cdot 163$ \\
\hline MFM-YE & $1 \cdot 72$ & $16 \cdot 150$ & $9 \cdot 390$ & $1 \cdot 10$ & 0.615 & 0.559 \\
\hline
\end{tabular}

* The final $Y_{\mathrm{CP} 5}$ is the concentration of type $5 \mathrm{CP}$ divided by the $\mathrm{OD}_{620}$ value for the bacterial suspension $\left[\mu \mathrm{g} \mathrm{CP}^{-1}\right.$ $\left.\left(\mathrm{OD}_{620} \text { unit }\right)^{-1}\right]$.

conjugate was added to the wells and the plate was incubated at $37^{\circ} \mathrm{C}$ for $45 \mathrm{~min}$. After washing with PBS/Tween, enzyme substrate was added and, after $10 \mathrm{~min}$ at room temperature, the reaction was stopped and the $A_{492}$ was read.

For each ELISA run, negative controls (wells not receiving test samples but PBS/Tween supplemented with $0.5 \%$ gelatin) and titration of purified CP were done to determine the sensitivity of the assay. A standard titration curve was plotted for the absorbance of serially diluted samples $\left(0 \cdot 06-1000 \mathrm{ng} \mathrm{ml}^{-1}\right)$ of purified $\mathrm{CP}$. The amounts of CP in the supernatants of autoclaved bacterial cell suspensions assayed at different dilutions were determined from the standard titration curve and expressed in $\mu \mathrm{g} \mathrm{ml}^{-1}$.

Chemicals. All chemicals were analytical or reagent grade and purchased from Prolabo or Merck.

Analysis of results. The type $5 \mathrm{CP}$ final specific yield (final $Y_{\mathrm{CP} 5}$ ) is defined as the total type $5 \mathrm{CP}\left(\mu \mathrm{g} \mathrm{ml}^{-1}\right)$ divided by the corresponding bacterial growth $\left(\mathrm{OD}_{620}\right)$ value at the end of growth.

\section{Results}

\section{Type 5 CP production in different classic media}

When grown on different solid media, $S$. aureus strain Reynolds exhibited significant variations in type $5 \mathrm{CP}$ production that were not correlated with total cell growth (Table 1). MFM-YE gave the highest specific yield of type $5 \mathrm{CP}$, and good results were also obtained with Medium 110. Type 5 CP production by strain Reynolds also varied in different liquid media (Table 2). CP production did not correlate with total cell growth or with the final $\mathrm{pH}$ of the culture. MFM-YE and MFMCA gave the highest yields, followed by Medium 110 .

In all media used, type $5 \mathrm{CP}$ was closely associated with the bacterial cell. The CP concentration in the supernatant never exceeded $5 \%$ of the total CP concentration, and washing in PBS did not result in removal of $\mathrm{CP}$ from the cells.
Table 2. Type 5 CP production by $S$. aureus strain Reynolds grown for $24 \mathrm{~h}$ in liquid media in shake flasks

Data shown are one representative set of data from five separate experiments. $Y_{\mathrm{CPS}}$ is defined in the footnote to Table 1.

\begin{tabular}{|c|c|c|c|c|}
\hline $\begin{array}{l}\text { Liquid } \\
\text { medium }\end{array}$ & $\mathrm{OD}_{620}$ & $\begin{array}{c}\text { Type } 5 \mathrm{CP} \\
\left(\mu \mathrm{g} \mathrm{ml}^{-1}\right)\end{array}$ & $\begin{array}{c}\text { Final } \\
Y_{\mathrm{CPS}}\end{array}$ & $\begin{array}{c}\text { Final } \\
\mathrm{pH}\end{array}$ \\
\hline Brain Heart Infusion & 7.98 & $2 \cdot 070$ & $0 \cdot 259$ & 7.83 \\
\hline Nutrient Broth & $2 \cdot 50$ & 0.620 & $0 \cdot 248$ & $8 \cdot 15$ \\
\hline Mueller-Hinton & 3.41 & 2.750 & 0.806 & $8 \cdot 16$ \\
\hline Columbia & 8.80 & 9.000 & 1.020 & 7.88 \\
\hline Medium 110 & $3 \cdot 15$ & $11 \cdot 300$ & 3.587 & 4.80 \\
\hline MFM-YE & $2 \cdot 18$ & $9 \cdot 250$ & $4 \cdot 243$ & $6 \cdot 11$ \\
\hline MFM-CA & 1.79 & $8 \cdot 140$ & 4.547 & 6.00 \\
\hline
\end{tabular}

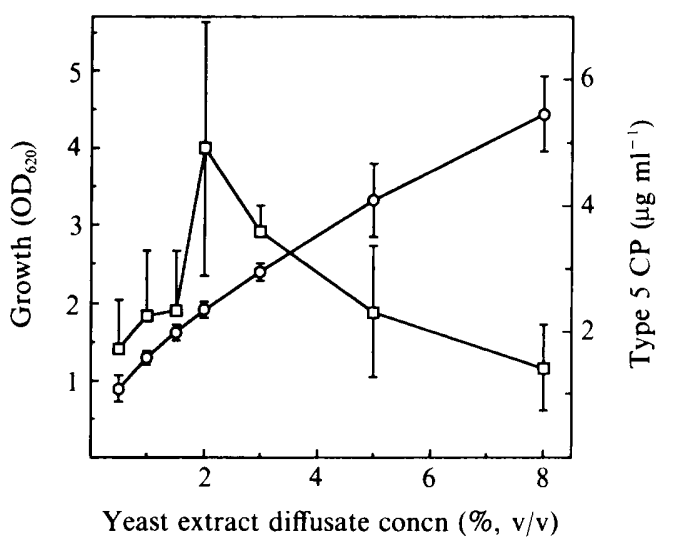

Fig. 1. Effect of yeast extract diffusate concentration (in MFM-YE) on growth $(O)$ and type $5 \mathrm{CP}$ production $(\square)$ by $S$. aureus strain Reynolds grown for $24 \mathrm{~h}$ in shake flasks. Overnight cultures from MFM-YE agar slants were used as inocula. Bars represent means \pm SEM of four independent experiments.

\section{Type 5 CP production in modified Frantz media}

The effects of the concentration of yeast extract diffusate in MFM-YE on growth and type $5 \mathrm{CP}$ production by strain Reynolds were examined in a series of shake flask experiments (Fig. 1). The final $\mathrm{pH}$ was, 


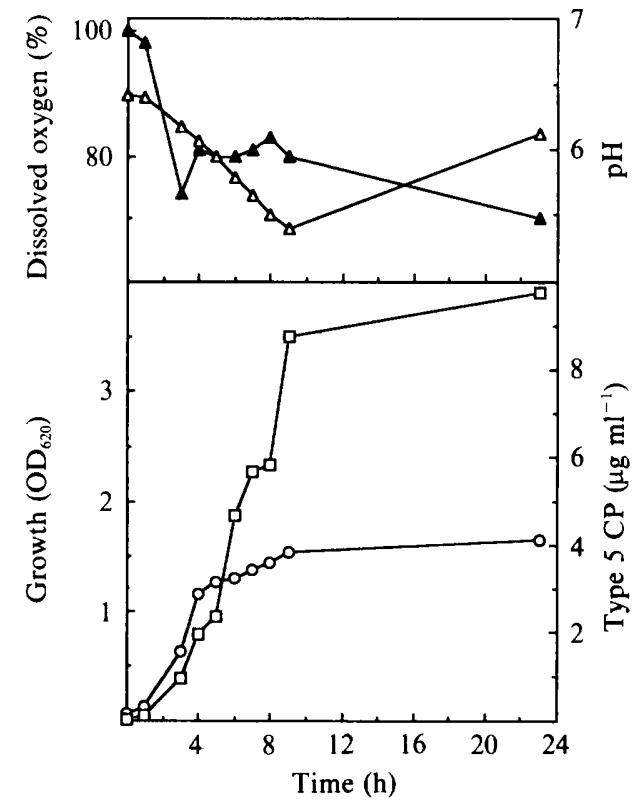

Fig. 2

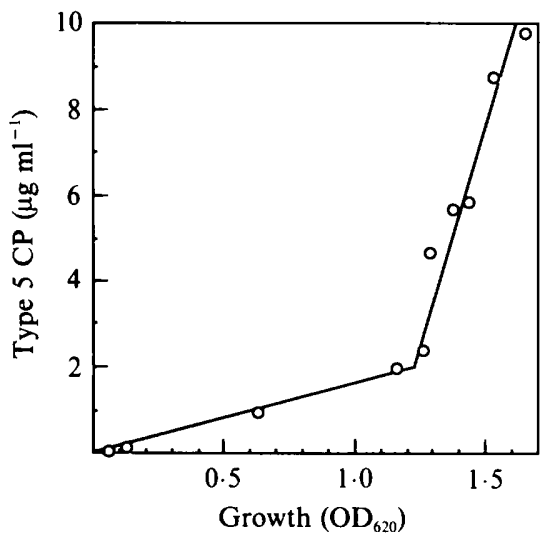

Fig. 3

Fig. 2. Growth $(O)$ and type $5 \mathrm{CP}$ production $(\square)$ by $S$. aureus strain Reynolds in MFM-YE in a fermenter without pH control. Dissolved oxygen; $\triangle, \mathrm{pH}$.

Fig. 3. Relationship between type $5 \mathrm{CP}$ production and growth of $S$. aureus strain Reynolds. The data are from the experiment depicted in Fig. 2.

respectively, 6.2, 6.5 and 6.9 in media containing $0.5,3$ and $8 \%(\mathrm{v} / \mathrm{v})$ yeast extract diffusate. Numbers of cells increased with the yeast extract concentration. Type 5 $\mathrm{CP}$ production rose with increasing yeast extract concentration up to $2 \%(\mathrm{v} / \mathrm{v})$, but fell at higher concentration. The same experiment done with increasing concentrations of Casamino acids diffusate (in MFM-CA) gave a similar peak of CP production at $2 \%$ (data not shown).

Type $5 \mathrm{CP}$ production in MFM-CA containing various carbon substrates was also examined in shake flasks. For this experiment, basal MFM-CA was prepared without lactose and glutamic acid, compounds that can be used as carbon sources by S. aureus (Keller $e t$ al., 1978). The carbon substrates, added at $2 \mathrm{~g} \mathrm{l}^{-1}$ to this basal medium, were: glucose, lactose, galactose, sucrose, maltose, mannose, mannitol, glycerol, sodium citrate, sodium pyruvate and glutamic acid. The addition of each of these carbon substrates increased the cell yield, compared to the basal medium, while the final $Y_{\mathrm{CP} 5}$ was not significantly different from one substrate to another (data not shown). MFM-YE base was not used for this experiment because yeast extract contains sugars (Atkinson \& Mavituna, 1983).

\section{Growth and type 5 CP production during batch culture}

Growth and type $5 \mathrm{CP}$ production by strain Reynolds were followed in MFM-YE in a fermenter, without $\mathrm{pH}$

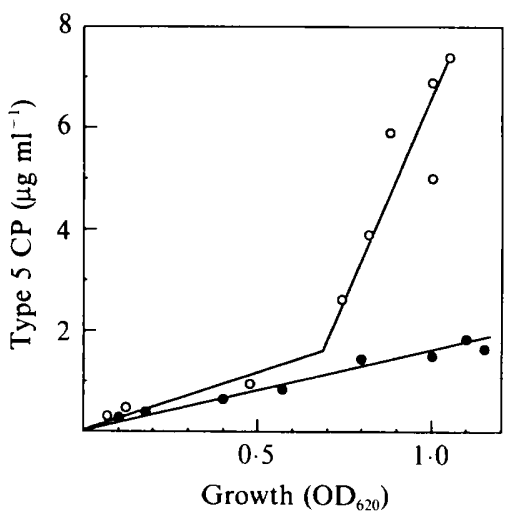

Fig. 4. Relationship between type $5 \mathrm{CP}$ production and growth of $S$. aureus strain Reynolds in MFM-YE in a fermenter with the $\mathrm{pH}$ controlled at $6.0(O)$ or $8.0(O)$.

control, for $24 \mathrm{~h}$ at $37^{\circ} \mathrm{C}$ (Fig. 2). Exponential growth continued for $4 \mathrm{~h}$, with a growth rate $\mu=0.75 \mathrm{~h}^{-1}$, followed by a slow growth phase for $5 \mathrm{~h}$ with a growth rate of about $0 \cdot 12 \mathrm{~h}^{-1}$. After $9 \mathrm{~h}$, no further growth was detectable. Type $5 \mathrm{CP}$ production lasted for $9 \mathrm{~h}$, during both exponential growth and slow growth phases, with a mean production rate $\mu_{C P}=0.65 \mathrm{~h}^{-1}$. At the end of the slow growth phase, production stopped. The $\mathrm{pH}$ decreased during the exponential growth and slow growth phases, and then increased during the stationary phase. From 24 to $48 \mathrm{~h}$, growth and type $5 \mathrm{CP}$ concentration did not change, but the $\mathrm{pH}$ continued to increase up to $7 \cdot 0$ 


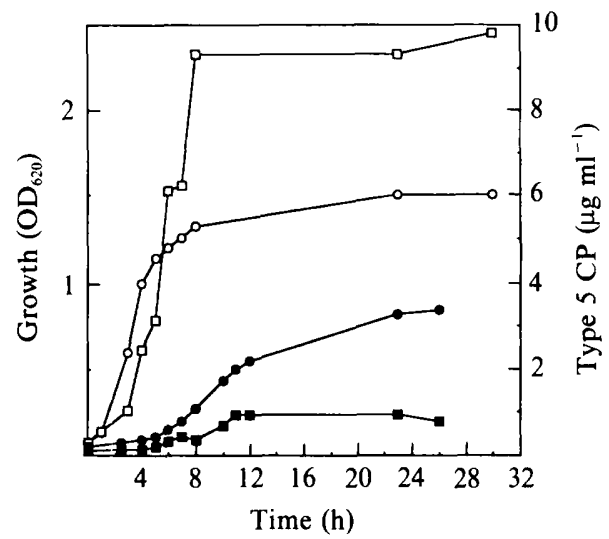

Fig. 5

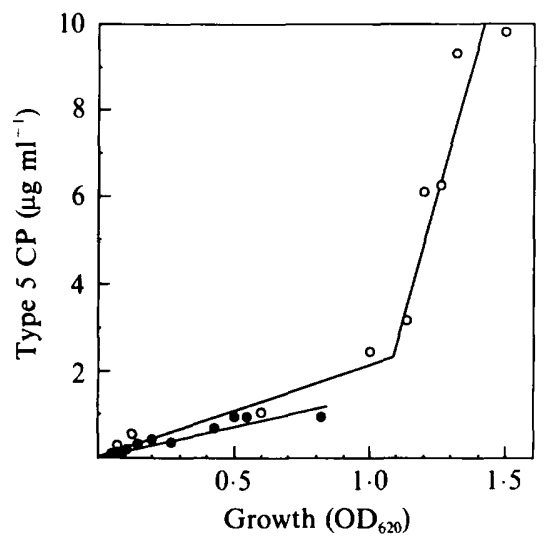

Fig. 6

Fig. 5. Growth $(O, \bigcirc)$ and type 5 CP production $(\square, \square)$ by $S$. aureus strain Reynolds in MFM-YE medium under aerobic (open symbols) or anaerobic (filled symbols) conditions, in a fermenter with the pH controlled at $\mathbf{7 \cdot 0 .}$

Fig. 6. Relationship between type 5 CP production and growth of $S$. aureus strain Reynolds under aerobic (O) and anaerobic conditions. The data are from the experiment depicted in Fig. 5.

(data not shown). Similar results were obtained with MFM-YE prepared with yeast extract at $2 \mathrm{gl}^{-1}$. The dialysis of yeast extract had no influence on $\mathrm{CP}$ production.

The relationship between type $5 \mathrm{CP}$ production and growth was further examined by plotting the $\mathrm{CP}$ concentration versus $\mathrm{OD}_{620}$ (Fig. 3). This gave two slopes, corresponding to the exponential growth phase and the slow growth phase. For cultures in MFM-YE in both shake flasks and fermenters (three independent cultures in each case) without $\mathrm{pH}$ control, the second slope was always eight- to ninefold higher than the first one, although the final $Y_{\mathrm{CP} 5}$ varied from one culture to another. This phenomenon was also observed in shake flask cultures with Brain Heart Infusion or Columbia media (data not shown).

\section{Influence of $p H$ control on type $5 \mathrm{CP}$ production}

When the pH was controlled at 6.0 (Fig. 4) or 7.0 (Figs 5 and 6) in a fermenter, CP was produced in both exponential and slow growth phases and there was the same correlation between the two slopes of a plot of CP production versus $\mathrm{OD}_{620}$. By contrast, when the $\mathrm{pH}$ was controlled at $8 \cdot 0$, the exponential growth rate decreased to $0.52 \mathrm{~h}^{-1}$, and CP production was proportional to cell mass for the whole growth period, giving only one slope on the CP versus $\mathrm{OD}_{620}$ plot (Fig. 4).

\section{Effect of anaerobic growth on type $5 C P$ production}

A comparison between growth on solid media with either loose or airtight caps (Table 1) showed that oxygen supply increased not only the total cell growth, but also the final $Y_{\text {CP5 }}$. Different final specific yield ratios were observed depending on the medium (Table 1).

Growth and type 5 CP production by strain Reynolds were followed under aerobic and anaerobic conditions in MFM-YE for $30 \mathrm{~h}$ in a fermenter maintained at $\mathrm{pH} 7.0$ and $37^{\circ} \mathrm{C}$ (Fig. 5). Results obtained under aerobic conditions at $\mathrm{pH} 7.0$ were the same as those obtained without $\mathrm{pH}$ control (Fig. 2). Under anaerobic conditions, the bacteria grew exponentially with a growth rate of $0.30 \mathrm{~h}^{-1}$, and the maximum cell mass was $55 \%$ of that obtained under aerobic conditions. Type $5 \mathrm{CP}$ production was proportional to the cell mass, with a mean production rate of $0.27 \mathrm{~h}^{-1}$ during the exponential growth phase. The final type $5 \mathrm{CP}$ concentration was tenfold lower than that observed under aerobic conditions. Plotting type $5 \mathrm{CP}$ production against growth gave two slopes under aerobic conditions and one slope under anaerobic conditions (Fig. 6).

\section{Discussion}

The amount of type $5 \mathrm{CP}$ formed by $S$. aureus strain Reynolds was influenced by the culture conditions. Comparison of the final specific yields presented in Tables 1 and 2 shows that variations in CP production followed similar patterns in both solid and liquid media. It seems that the physical state of the culture medium has little influence on CP production. The same observation was made with Haemophilus influenzae (Anderson et al., 1976). In contrast, important variations in the expression of cell wall proteins have been observed for staphylococci 
grown in liquid as opposed to solid media (Cheung \& Fischetti, 1988).

Our work confirms earlier findings of enhanced CP production by $S$. aureus grown in Medium 110 (Caputy \& Costerton, 1984; Yoshida \& Ekstedt, 1968). We describe a medium that is simpler than Medium 110, but which is as efficient for CP production, despite its low concentrations of salt and carbohydrate, two factors which were assumed to be important for capsule production (Yoshida \& Ekstedt, 1968). Media closely related to our semi-synthetic medium, containing Casamino acids and glycerol, have been used previously for the study of capsule formation by $S$. aureus (Wiley, 1968; Witte, 1975).

Exopolysaccharide production is dependent on the available carbon source for bacteria such as Streptococcus pneumoniae, Escherichia coli, Lactobacillus, Pseudomonas, Agrobacterium and Erwinia, and both the amount and composition of the capsular material can be affected (Linton, 1990; Sutherland, 1988; Wilkinson, 1958). Our results show that there is no such dependence for type 5 $C P$ production by $S$. aureus strain Reynolds. The multiplicity of catabolic pathways and the ability of $S$. aureus to utilize various carbon sources under both aerobic and anaerobic conditions might explain this lack of influence of specific carbon source on $\mathrm{CP}$ production (Wilkinson, 1958).

High concentrations of dialysed yeast extract in MFM-YE (above $2 \% \mathrm{v} / \mathrm{v}$ ) inhibited CP formation. High levels of yeast extract diffusate have been shown to inhibit delta-haemolysin production by $S$. aureus (Turner, 1978). One or several inhibitory factors might be present in yeast extract. For the production of CP, such factors may be UMP and UDP, which strongly inhibit the synthesis of lipid-linked sugar intermediates (Chiu, 1988).

Production of capsular material during growth of $S$. aureus has been previously observed (Kitzrow et al., 1975; Wiley, 1968), but the relationship of CP production to growth had not been investigated. In the present study, type $5 \mathrm{CP}$ synthesis by strain Reynolds was shown to continue when cell growth slows down, and $C P$ production in the post-exponential growth phase contributed at least half the final amount of CP measured. Significant post-exponential polysaccharide production has been observed with other bacteria such as Lactobacillus (Dunican \& Seeley, 1965), H. influenzae (Anderson et al., 1976), Aerobacter (Wilkinson, 1958) and Azotobacter (Sutherland, 1988). As the pH continues to decrease after the end of the exponential phase, it can be surmised that lactose was still available for polysaccharide synthesis during the slow growth phase. Substances not required for polysaccharide synthesis but which act as growthlimiting nutrients should give an increased amount of polysaccharide per cell. When these substances are depleted, the synthesis of protein and most growth factors is inhibited, but the production of polysaccharides and lipids may continue (Wilkinson, 1958). Furthermore, the study of specific activities of precursorforming enzymes involved in the formation of exopolysaccharide by Pseudomonas showed a constitutive biosynthetic system (Williams \& Wimpenny 1980).

Post-exponential production of exoproteins by several $S$. aureus strains has also been observed (Coleman et al., 1978; Schlievert \& Blomster, 1983). The ratio of exoproteins to bacterial density increased after the end of the exponential growth phase, and was interpreted as a competition between intracellular protein and exoprotein synthesis.

$\mathrm{pH}$ influences the production of exopolysaccharides by several bacterial species (Masson \& Holbein, 1985; Wilkinson, 1958). Using the serum/soft agar technique, Chomarat et al. (1989) found that certain S. aureus strains that possessed capsular antigen and formed diffuse-type colonies at $\mathrm{pH} 7.2$ exhibited compact growth at $\mathrm{pH} 8 \cdot 4$, corresponding to a non-capsulated phenotype. Our results also indicate that $\mathrm{pH}$ influences $\mathrm{CP}$ synthesis by strain Reynolds. CP production was sustained after the exponential growth phase in the $\mathrm{pH}$ range 6.0-7.0, but at $\mathrm{pH} 8.0$ there was no continuation of $\mathrm{CP}$ synthesis after the end of this phase, and the final specific yield of CP was significantly lower.

The comparison between cells grown on agar slants with loose and airtight caps had previously been made but with Columbia medium only (Hochkeppel et al., 1987). Results from fermenter cultures confirmed that oxygen supply increased $\mathrm{CP}$ production and allowed the continuation of $\mathrm{CP}$ synthesis after the end of the exponential growth phase. Higher oxygen supply enhances exopolysaccharide production by Pseudomonas (Bayer et al., 1990), Alcaligenes (Lawford \& Rousseau, 1989) and Xanthomonas (Suh et al., 1990). It is assumed that cells actively synthesizing exopolysaccharide have an oxygen demand associated with the energy requirements for biosynthesis (Linton, 1990; Wilkinson, 1958). The intracellular energy level could also explain the higher exoprotein production by $S$. aureus in aerobic as opposed to anaerobic culture (Coleman, 1985; Jarvis et al., 1973; Schlievert \& Blomster, 1983).

The culture system developed here could be a useful tool in future investigations on the physiology of $\mathrm{CP}$ production by $S$. aureus. Furthermore, the use of a simple medium containing only low molecular mass components will facilitate isolation of the polysaccharide for clinical investigation and vaccine development.

We are grateful to F. Nato and J. C. Mazie (Hybridolab, Institut Pasteur, Paris) for providing monoclonal antibodies to $S$. aureus capsular polysaccharide type 5 . 


\section{References}

Albus, A., Fournier, J. M., Wolz, C., Boutonnier, A., Ranke, M. HøIBY, N., HochKePPEl, H. \& DöRING, G. (1988). Staphylococcus aureus capsular types and antibody response to lung infection in patients with cystic fibrosis. Journal of Clinical Microbiology 26 , 2505-2509.

Anderson, P., PITt, J. \& SMith, D. H. (1976). Synthesis and release of polyribophosphate by Haemophilus influenzae type b in vitro. Infection and Immunity 13, 581-589.

ARbeit, R. D., Karakawa, W. W., VanN, W. F. \& Robbins, J. B. (1984). Predominance of two newly described capsular polysaccharide types among clinical isolates of Staphylococcus aureus. Diagnostic Microbiology and Infectious Diseases 2, 85-91

Atkinson, B. \& Mavituna, F. (1983). Biochemical Engineering and Biotechnology Handbook, p. 61. New York: The Nature Press/Macmillan.

Bayer, A. S., Eftekhar, F., Tu, J., Nast, C. C. \& Speert D. P. (1990) Oxygen-dependent up-regulation of mucoid exopolysaccharide (alginate) production in Pseudomonas aeruginosa. Infection and Immunity 58, 1344-1349.

Boutonnier, A., Nato, F., Bouvet, A., Lebrun, L., Audurier, A., MAzie, J. C. \& Fournier, J. M. (1989). Direct testing of blood cultures for detection of the serotype 5 and 8 capsular polysaccharides of Staphylococcus aureus. Journal of Clinical Microbiology 27, 989-993.

CAPUty, G. G. \& Costerton, J. W. (1984). Immunological examination of the glycocalyces of Staphylococcus aureus strains Wiley and Smith. Current Microbiology 11, 297-302.

Cheung, A. L. \& Fischetti, V. A. (1988). Variation in the expression of cell wall proteins of Staphylococcus aureus grown on solid and liquid media. Infection and Immunity 56, 1061-1065.

CHIU, T. (1988). Biosyntheses of galactosyl lipids and polysaccharide in Streptococcus mutans. Biochimica et Biophysica Acta 963, 359-366.

Chomarat, M., IChiman, Y. \& Yoshida, K. (1989). Protection of mice by a pseudodiffuse strain of Staphylococcus aureus possessing polyvalent capsular type antigen. Journal of Medical Microbiology 28, 129-136.

Coleman, G. (1985). A comparison of the patterns of extracellular proteins produced by the high $\alpha$-toxin-secreting organism Staphylococcus aureus (Wood 46) during aerobic and anaerobic growth. Journal of General Microbiology 131, 405-408.

Coleman, G., Jakeman, C. M. \& Martin, N. (1978). Patterns of total extracellular protein secretion by a number of clinically isolated strains of Staphylococcus aureus. Journal of General Microbiology 107 , 189-192.

DuniCAN, L. K., \& SEElEy, H. W. (1965). Extracellular polysaccharide synthesis by members of the genus Lactobacillus: conditions for formation and accumulation. Journal of General Microbiology $\mathbf{4 0}$ 297-308.

Falcieri, E., Vaudaux, P., Huggler, E., Lew, D. \& Waldvogel, F. (1987). Role of bacterial exopolymers and host factor on adherence and phagocytosis of Staphylococcus aureus in foreign body infection. Journal of Infectious Diseases 155, 524-531.

Fournier, J. M., Hannon, K., Moreau, M., Karakawa, W. W. \& VANN, W. F. (1987). Isolation of type 5 capsular polysaccharide from Staphylococcus aureus. Annales de l'Institut Pasteur/Microbiologie 138, $561-567$.

GotTsChlich, E. C., Yung LiU, T. \& ARtenstein, M. S. (1969) Human immunity to the meningococcus. III. Preparation and immunochemical properties of the group A, group B, and group C meningococcal polysaccharides. Journal of Experimental Medicine 129, 1349-1365.

Hochkeppel, H. K., Braun, D. G., Vischer, W., Imm, A., Sutter, J., Staeubli, U., Guggenheim, R., Kaplan, E. L., Boutonnier, A. \& FouRNIER, J. M. (1987). Serotyping and electron microscopy studies of Staphylococcus aureus clinical isolates with monoclonal antibodies to capsular polysaccharide type 5 and 8 . Journal of Clinical Microbiology 25, 526-530.

Huber, M. M. \& Huber, T. W. (1989). Susceptibility of methicillinresistant Staphylococcus aureus to lysostaphin. Journal of Clinical Microbiology 27, 1122-1124.
Jarvis, A. W., Lawrence, R. C. \& Pritchard, G. G. (1973). Production of staphylococcal enterotoxins $A, B$ and $C$ under conditions of controlled $\mathrm{pH}$ and aeration. Infection and Immunity 7 , 847-854.

JENNINGS, H. J. (1990). Capsular polysaccharides as vaccine candidates. Current Topics in Microbiology and Immunology 150, 97-127.

JOHNE, B., JARP, J. \& HAAHEIM, L. R. (1989). Staphylococcus aureus exopolysaccharide in vivo demonstrated by immunomagnetic separation and electron microscopy. Journal of Clinical Microbiology 27. 1631-1635.

Karakawa, W. W., Fournier, J. M., VanN, W. F., Arbeit, R., SCHNEERSON, R. S. \& Robbins, J. B. (1985). Method for the serological typing of the capsular polysaccharides of Staphylococcus aureus. Journal of Clinical Microbiology 22, 445-447.

KARAKaWA, W. W. \& VANN, W. F. (1982). Capsular polysaccharides of Staphylococcus aureus. Seminars in Infectious Diseases 4, 285-293.

Keller, G. M., HaNSON, R. S. \& Bergdoll, M. S. (1978). Molar growth yields and enterotoxin B production of Staphylococcus aureus S-6 with amino acids as energy sources. Infection and Immunity 20, $151-157$.

Kitzrow, D., Blobel, H. \& SchaEg, W. (1975). Isolation of capsular substances from Staphylococcus aureus. Zentralblatt für Bakteriologie, Mikrobiologie und Hygiene (Series A) 233, 305-313.

LAWFORD, H. \& RoUSSEAU, J. (1989). Effect of oxygen on the rate of $\beta$ 1,3-glucan microbial exopolysaccharide production. Biotechnology Letters 11, 125-130.

Lee, J. C., Betley, M. J., Hopkins, C. A., Perez, N. E. \& Pier, G. B. (1987). Virulence studies, in mice, of transposon-induced mutants of Staphylococcus aureus differing in capsule size. Journal of Infectious Diseases 156, 741-750.

LINTON, J. D. (1990). The relationship between metabolite production and the growth efficiency of the producing organism. FEMS Microbiology Reviews 75, 1-18.

Luong, J. H. T., Mulchandani, A. \& Leduy, A. (1988). Kinetics of biopolymer synthesis: a revisit. Enzyme and Microbial Technology 10, 326-332.

Masson, L. \& Holbein, B. E. (1985). Influence of nutrient limitation and low $\mathrm{pH}$ on serogroup $\mathrm{B}$ Neisseria meningitidis capsular polysaccharide level: correlation with virulence for mice. Infection and Immunity 47, 465-471.

MatTILA, T. (1989). A staining technique to measure capsular polysaccharides of Staphylococcus aureus on filter membranes. Journal of Microbiological Methods 9, 323-331.

Opdebeeck, J. P., O’Boyle, D. \& Frost, A. J. (1985). The expression of capsule in serum-soft agar by Staphylococcus aureus isolated from human clinical sources. Journal of Medical Microbiology 19, 275278.

Opdebeeck, J. P., Watson, D. L. \& Frost, A. J. (1988). Colony morphology of Staphylococcus aureus in serum-soft agar following in vivo and in vitro growth. Veterinary Microbiology 16, 87-91.

Paul, F., Morin, A. \& Morsan, P. (1986). Microbial polysaccharides with actual potential industrial applications. Biotechnological $\boldsymbol{A} d$ vances $4,245-259$.

Poutrel, B., Boutonnier, A., Sutra, L. \& Fournier, J. M. (1988). Prevalence of capsular polysaccharide types 5 and 8 among Staphylococcus aureus isolates from cow, goat, and ewe milk. Journal of Clinical Microbiology 26, 38-40.

Rather, P. N., Davis, A. P. \& Wilkinson, B. J. (1986). Slime production by bovine milk Staphylococcus aureus and identification of coagulase-negative staphylococcal isolates. Journal of Clinical Microbiology 23, 858-862.

Robins, J. B. \& SchneERson, R. S. (1990). Polysaccharide-protein conjugates: a new generation of vaccines. Journal of Infectious Diseases 161, 821-832.

Roberts, I. S., SAunders, F. K. \& Boulnois, G. J. (1989). Bacterial capsules and interactions with complement and phagocytes. Biochemical Society Transactions 17, 462-464.

Schlievert, P. M. \& Blomster, D. A. (1983). Production of staphylococcal pyrogenic exotoxin type C: influence of physical and chemical factors. Journal of Infectious Diseases 147, 236-242.

SHEAGREN, J. N. (1984). Staphylococcus aureus: the persistent pathogen. New England Journal of Medicine 310, 1368-1373, 14371442 . 
Sompolinsky, D., Samra, Z., Karakawa, W. W., Vann, W. F., SCHNEERSON, R. \& MALIK, Z. (1985). Encapsulation and capsular types in isolates of Staphylococcus aureus from different sources and relationship to phage types. Journal of Clinical Microbiology 22, 828834.

SuH, I. S., Herbest, H., Schumpe, A. \& DeCkwer, W. D. (1990). The molecular weight of xanthan polysaccharide produced under oxygen limitation. Biotechnology Letters 12, 201-206.

SUTHERLAND, I. W. (1988). Bacterial surface polysaccharides: structure and function. International Review of Cytology 113, 187-231.

TURNER, W. H. (1978). The effect of medium volume and yeast extract diffusate on delta-hemolysin production by five strains of Staphylococcus aureus. Journal of Applied Bacteriology 45, 291-296.

WhitFIELD, C. (1988). Bacterial extracellular polysaccharides. Canadian Journal of Microbiology 34, 415-420.

WILEY, B. B. (1968). Capsule size, coagulase production, and egg virulence among certain strains of Staphylococcus aureus. Canadian Journal of Microbiology 14, 685-689.

WILKINSON, J. F. (1958). The extracellular polysaccharides of bacteria. Bacteriological Reviews 22, 46-73.

Williams, A. G. \& WimpenNy W. T. (1980). Extracellular polysaccharide biosynthesis by Pseudomonas NCIB 11264. Studies on precursorforming enzymes and factors affecting exopolysaccharide production by washed suspensions. Journal of General Microbiology 116, $133-141$.

WITTE, W. (1975). Capsule formation in Staphylococcus aureus as a reason for nontypability by phages. Zentralblatt für Bakteriologie, Mikrobiologie und Hygiene (Series A) 233, 447-451.

YoshidA, K. \& EKsTEDT, R. D. (1968). Relation of mucoid growth of Staphylococcus aureus to clumping factor reaction, morphology in serum-soft agar, and virulence. Journal of Bacteriology 96, 902-908. 